The report does not say specifically what the value of the timber of Pinus contorta Doug. is compared with that of other trees, information which would be of the utmost importance to the forester. The structure of its wood is said to be intermediate between, for example, yellow pine and Scots pine. There is some slackness in nomenclature in the report; apart from leaving one in doubt about what yellow pine is, the terms 'redwood' and 'whitewood' are still used with no explanation that the former is wood of Scots pine and the latter that of Norway spruce. The laboratory should think of the grower as well as of the user.
It is almost certain that timbers will long remain among the most useful of raw materials, and the more we can learn about them the better. As the chairman of the Forest Products Research Steering Committee in his introduction says, there is no lack of work to be done, but why is all the work kept in the south of Britain? Some could be done just as well at a properly equipped laboratory in the north. The Committee has a difficult task in avoiding the many reefs and in selecting the most profitable waters. The greater attention now being given to home- (and Irish-) grown timbers is, however, likely to be fully justified.
M. L. Anderson

\title{
DRUG SUPPLIES DURING THE AMERICAN REVOLUTION
}

TITIALLY, drug supplies for the American Revolutionary Army came from stocks largely in the hands of private druggists. This source of supply was totally inadequate for a war that attained such proportions as the Revolution. Even if stocks of drugs in the Colonies had been far greater than they were, there is little reason for believing that shortages would not have developed. Even the most patriotic pharmacists were faced with complete financial suicide, caught between a spiralling inflation and a Congress that had no money and only a promise for the future. In an interesting paper, George B. Griffenhagen, formerly curator of medical sciences, U.S. National Museum, Smithsonian Institution (Bull. 225), shows how the internal organization of the medical department of the army was so chaotic that, even if adequate supplies were available and if the almost unsurmountable problems of communications and transportation had been solved, it is almost certain that shortages would have developed at least during the campaign of 1776.

The encouragement which Congress, through its Secret Committee, gave to private shippers for the importation of vital war supplies offered little relief in the field of medical supplies. Importation was cut off from Great Britain, and. France did not directly export any quantities of medical supplies, at least until 1778. American privateers found it much more profitable to prey on British shipping than to develop trade channels with countries which, prior to the Revolution, were prohibited from shipping directly to the Colonies.

Hence, the most immediate relief from medical supply shortages was provided by the American privateers. Drug cargoes from British prize ships, many of which were en route to New York, served as a most important source of supply, particularly during 1777 and 1778 .

The number of individual drugs mentioned in various inventories was considerable. Of these, only about a dozen were critically short. Heading the list of these 'capital articles' was Peruvian bark, the same cinchona from which quinine was later discovered. Tons of bark were used during the Revolutionary War, and the price more than quadrupled between June 1776 and September 1777 .

The most prominent group of drugs on the list of capital articles consisted of catharties and purgatives. Jalap, ipecac, and rhubarb were the botanical favourites, while bitter purging salt (Epsom salts) and Glauber's purging salts were the chemical choices for purging. Tartar emetic was the choice for a vomit, and cantharides (Spanish flies) was the most important ingredient for blistering plasters. Opium was administered for its narcotic effects, while gum camphor, nitre (saltpetre or potassium nitrate), and mercury (pure metal as well as certain salts) were employed for a variety of purposes. Lint, a form of absorbent material made by scraping or picking apart old woven material, was also in short supply.

Equipment shortages included surgical instruments and mortar, and pestles for pulverizing crude drugs. Glass vials for holding compounded medicines were also a supply problem, especially after essential drugs again became available. Some of the shortages were eased by local manufacture. Lint was produced in large quantities in the Colonies, and glass vials were manufactured in numerous glasshouses. Local manufacture of purging salts and nitre aided in eliminating shortages of these essential items, and, at the same time led to the first large-scale pharmaceutical manufacturing in the United States.

\section{$\pi$-ELECTRONIC EXCITATION AND IONIZATION ENERGIES OF CONDENSED RING AROMATIC HYDROCARBONS}

\author{
By DR. J. B. BIRKS and M. A. SLIFKIN \\ Physical Laboratories, University of Manchester
}

\begin{abstract}
$\mathrm{T}$ HE condensed ring aromatic hydrocarbons form an interesting group of molecules. They possess delocalized $\pi$-electron systems, loosely bound by a potential defined by the shape of the planar molecular skeleton; they scintillate, fluoresce and phosphoresce;
\end{abstract}

some of the higher members are careinogenic; and they possess certain well-defined electronic energylevels which vary systematically with molecular size. They have been the subject of many theoretical studies, including those based on the molecular 